\title{
Deleuze e o Eterno Retorno da Diferença
}

\author{
Ovídio de Abreu \\ ovidio.abreu@terra.com.br \\ Universidade Federal Fluminense, Niterói, Rio de Janeiro, Brasil
}

resumo Esse texto tem em vista um problema e um conceito: o problema da seleção ética como melhor problema do que o julgamento como uma solução moral, e o conceito de "eterno retorno", tal como circunscrito pela interpretação que Deleuze faz da filosofia de Nietzsche.

palavras-chave Deleuze; eterno retorno; diferença; repetição; ética

"O pensamento não tem outro funcionamento que o seu próprio nascer, sempre a repetição de seu nascimento, oculto e profundo." Gilles Deleuze.

Para ultrapassar uma compreensão abstrata da filosofia de Deleuze é preciso compreender a maneira pela qual ela faz ecoar o imperativo nietzschiano da subversão do platonismo. Deleuze não o retoma sob o modo de uma identificação, mas o faz ressoar com um outro imperativo, inspirado em Bergson, segundo o qual o que importa para a filosofia não é mais "como atingir o Eterno, mas em que condições o mundo objetivo permite uma produção subjetiva de novidade, ou seja, uma criação" (DELEUZE, 1991, p.121). E esses confluem ainda com outros, provenientes de Hume (as relações são exteriores aos termos relacionados) e de Espinosa (Deus ou Natureza, protestos em favor da imanência). Ao retomá-los, Deleuze os envolve num clamor cósmico, "Para dar fim ao julgamento de Deus!”, emitido por Antonin Artaud. Deleuze extrai dessa glossolalia filosófica sua própria exclamação: que toda coisa seja um acon- 


\section{8}

tecimento! Tais imperativos o conduzem a elaborar uma filosofia da diferença e da repetição, que se desdobra e compreende o pensamento, o sentido, o desejo, as multiplicidades, a criação como acontecimentos.

Por que uma filosofia da diferença? Por muitas razões. Porque, em um dado momento, a hora chega para isso, porque a questão vinha na ordem do dia, mas, sobretudo porque há um desejo de Deleuze de fazer avançar a linhagem filosófica que trabalhou para tornar vergonhosa a vontade moral de julgar e depreciar a vida. Espinosa e Nietzsche participam dessa linhagem, mas também certas singularidades da filosofia de Bergson e de Hume. Sem contar as obras de Proust e de Artaud, nas quais Deleuze também aponta renovações da imagem de pensamento. A lista de intercessores é longa, inclui cientistas, matemáticos, poetas, romancistas, dramaturgos, pintores, músicos, cineastas, etc. Nunca se pensa sozinho! Deleuze não se cansou de retomar essa ideia, de insistir nela, de evoluir em torno dela.

Mas por que uma filosofia da diferença? Por uma razão muito simples: Deleuze, ao fazer ecoar o grito de Nietzsche que conclama a filosofia do futuro à tarefa de subverter o platonismo, mostrou o quanto a motivação da filosofia de Platão é sobretudo moral e como essa motivação introduziu uma transcendência no plano de imanência filosófico, uma transcendência filosoficamente plausível: a Ideia, como forma transcendente, eternamente idêntica a si mesma, que permite fazer a triagem entre o que é conforme à ideia (a cópia) e o que não lhe é conforme (o simulacro). E o aquilo não se identifica espiritualmente com a Ideia como Modelo, vale dizer, o que escapa ao Mesmo, a diferença, não deve ser apenas recalcado, excluído, mas, sobretudo, deve ser desfigurado. Subverter o platonismo significa afirmar a diferença (simulacro), e essa afirmação exige um pensamento capaz de aliviá-la do longo jugo aos critérios da Identidade no conceito, da Analogia no juízo, da Oposição no predicado e da Semelhança na percepção. Criar uma filosofia da diferença significa, primeiramente, elaborar problemas e conceitos capazes de resistir ao desejo de julgar e depreciar a vida. Sobretudo Nietzsche e Espinosa mostraram que a vontade de depreciar a vida é inseparável de um conluio do pensamento com sistemas de poderes internos e externos ao campo filosófico.

Estudos sobre a abordagem da história da filosofia por Deleuze ainda serão bem vindos: pesquisas sobre a sua maneira de remontar dos 
conceitos aos problemas que lhes dão sentido, de indissociar-se dos pensadores que estuda de modo a produzir um campo de intensidades, uma região de indiscernibilidades, lá onde ele próprio, Deleuze, pode criar com eles, retomando, prolongando e renovando o pensamento. Minha incursão por essa zona de indiscernibilidades tem em vista um problema e um conceito: o problema da seleção ética como melhor problema do que o julgamento como uma solução moral, e o conceito de "eterno retorno", tal como circunscrito pela interpretação que Deleuze faz da filosofia de Nietzsche.

Mas por que esse problema e esse conceito? O problema de uma seleção ética imanente, não referida a normas transcendentes — seja a modelos metafisicos, seja a valores constituídos ou a imperativos do Estado, ou ainda a "necessidades" de uma ordem social estabelecida responde ao imperativo de dar fim ao julgamento de Deus ou do Homem. O conceito de eterno retorno da diferença deve ser compreendido como uma resposta ao problema da seleção imanente, tal como desenvolvida na filosofia de Deleuze.

Assim, é do ponto de vista do eterno retorno que se deve compreender a repetição, na obra de Gilles Deleuze, da questão "o que significa pensar, quando pensar não é julgar?”. Se a hipótese se sustenta, ela deve facultar, em consequência, que outra hipótese se formule: a saber, a questão do combate à doutrina do julgamento, articulada ao problema "o que significa pensar?" que a desenvolve, deve ser definida como questão crítica. Essa questão põe e ordena o problema de uma filosofia da diferença e da repetição, retomada sempre que solicitada por novos problemas que se encadeiam ao longo da obra de Deleuze dedicada a dar consistência à ideia de uma filosofia como construção de problemas e como criação de conceitos necessários ao prolongamento do combate filosófico contra a doutrina do julgamento que apoia a filosofia da representação. Portanto, a filosofia da diferença encontra no pensamento do eterno retorno - ou melhor, na interpretação deleuziana da doutrina do eterno retorno - a vitalidade necessária e a forma adequada para pôr, nos seus próprios termos, o problema do sentido do pensamento. O pensamento, segundo essa orientação, não pode, de direito, ser objetivado e só admite o problema "o que significa pensar?" como questionamento que submete o ato de pensar - o maior acontecimento - à prova do seu eterno retorno. 


\section{Deleuze intérprete de Nietzsche}

A filosofia, tal como a concebe Deleuze com Nietzsche, é um pensamento crítico e criador. Sua crítica incide sobre as ficções que compõem, no pensamento, a vitória das forças reativas sobre as forças ativas. Desse modo, a crítica filosófica interpela a vontade que se exprime nas forças que compõem uma imagem do que é o pensamento. Por essa razão, a crítica criativa compromete-se com a questão: o que é pensar? ${ }^{1} \mathrm{Na}$ contracorrente da metafisica, a filosofia nietzschiana afirma um pensamento que se propõe como crítico dos valores e, ao determinar o problema crítico como o da avaliação do valor dos valores, põe sob suspeição os sentidos da crítica na metafísica, no idealismo transcendental, no movimento filosófico dos jovens hegelianos. Segundo Nietzsche, os valores não se podem pretender como princípios, pois, mais profundamente, os valores supõem avaliações de onde derivam os seus próprios valores. Os valores transcendentes não resistem a essa suspeita filosófica: sua pretensão à eternidade se desvanece com a exposição de sua gênese. Isto porque “as avaliações, relacionadas ao seu elemento, não são valores, mas maneiras de ser, modos de existência daqueles que julgam e avaliam, servindo precisamente de princípios aos valores" (DELEUZE, 1962, p.1-2). Esse golpe de misericórdia na pretensão de um fundamento transcendente retira da crítica todo apoio ou referência meta-situada. Do ponto de vista de Deleuze, porém, a ausência de valores transcendentes não afeta apenas a crítica. O sentido próprio da filosofia modifica-se.

Se a interpretação original da doutrina do eterno retorno assegura que o espírito da crítica nietzschiana seja incorporado pela filosofia deleuziana, será proveitoso investigar, com mais detalhe, como Deleuze define esta crítica e de que modo, através de que conceitos, ele revela, no pensamento de Nietzsche, as condições de uma crítica verdadeiramente imanente.

Deleuze apresenta a filosofia de Nietzsche como orientada segundo dois eixos: um referido às forças, que desenvolve uma semiologia original; outro relativo à potência, que elabora uma ética e uma ontologia. Do ponto de vista das forças, o fenômeno não é nem aparência nem uma aparição: é um signo que encontra seu sentido em uma relação de forças. Com esse conceito, Deleuze evita a dualidade metafísica da aparência e 
da essência, o par aparição/condição da aparição característico do idealismo transcendental, bem como a relação "científica" de causa e efeito. O signo, como expressão de uma coexistência de forças em combate, resulta do acaso de uma multiplicidade de forças em devir. Como sintoma, o signo é um "objeto" portador de problema. Nessa medida, como efeito de relações de forças e como portador de problema, todo signo envolve uma coexistência de sentidos.

Do ponto de vista da vontade de potência, as forças em relação exprimem-se em qualidades dinâmicas da vontade, afirmativa ou negativa. Considerada como elemento genético interno à relação diferencial das forças constituintes de qualquer coisa, a potência não pode ser objeto da vontade; ao contrário, conforme à célebre fórmula de Deleuze: “a potência não é o que a vontade quer, mas, ao contrário, é quem quer na vontade" (DELEUZE, 2009, p. 23-24).

Nietzsche questiona o conceito de verdade e não reconhece o verdadeiro como elemento da linguagem e do pensamento. Daí sua contestação das noções de verdadeiro e de falso em favor das noções de sentido e valor. Essas noções são essencialmente críticas e criadoras: questionam as verdadeiras formas da Moral e do Verdadeiro e não seus falsos conteúdos; ao mesmo tempo, possibilitam pensar a transvaloração de todos os valores e a criação de outros e novos modos de pensar, de viver e de sentir. Além disso, o sentido não é posto como dado, nem como um princípio, nem mesmo como um fim: é pensado como um efeito, a expressão de relações de forças que não têm sentido nelas mesmas. Nietzsche cria um novo conceito de interpretação. Para ele, interpretar não é uma hermenêutica ou um desvelamento de um sentido oculto, já dado previamente como tal, mas a posição de novos sentidos: interpretar é criar, é o ato complexo, com durações variáveis, de criação de novos sentidos que se atribuem aos seres e às coisas.

\section{0 eterno retorno da diferença}

A interpretação de Deleuze da doutrina do Eterno Retorno do Mesmo faz com que o mesmo se diga da diferença e compreende o andamento do eterno retorno como um movimento seletivo. Esta interpretação 
retoma, por sua conta, o problema, montado por Nietzsche, relativo à afirmação trágica da existência.

Após sublinhar os limites da compreensão do trágico em O nascimento da tragédia, Deleuze argumenta que Nietzsche acede ao sentido do trágico quando substitui a pergunta "a existência culpada é responsável ou não?" por esta outra questão - "a existência é culpada ou inocente?" -, que encontra como sua solução a afirmação da inocência de tudo o que é: do acaso, da multiplicidade e do devir.

Essa aproximação permite compreender a razão da inflexão impressa por Deleuze à doutrina nietzschiana do Eterno Retorno do Mesmo. A interpretação desenvolvida por Deleuze, ao fazer o Mesmo se dizer da Diferença no pensamento do eterno retorno, introduz neste pensamento um componente seletivo comprometido com a afirmação da diferença, que envolve a afirmação do acaso (a diferença 'entre todos' ou distributiva), do múltiplo (a diferença entre o um e o outro) e do devir (a diferença de si mesmo). Essa interpretação do eterno retorno da diferença direciona a pesquisa de uma nova imagem do pensamento, na qual o acaso, a multiplicidade e o devir se dizem do próprio pensamento.

É neste sentido que Nietzsche e a filosofia retoma a distinção, proposta por Nietzsche, entre dois aspectos que coexistem na ideia do eterno retorno: o eterno retorno como doutrina cosmológica e física e o eterno retorno como pensamento ético e seletivo. A doutrina cosmológica e fisica do eterno retorno constitui, inicialmente, uma afirmação do devir. Este pensamento exige que o devir não tenha começo nem fim: "que o instante atual não seja um instante de ser ou de presente 'no sentido estrito', que ele seja um instante que passa, força-nos a pensar o devir, mas a pensá-lo precisamente como aquilo que não pode começar e como aquilo que não pode parar de devir." (DELEUZE, 1962, p.54). Essa doutrina ainda deve afirmar o ser do devir para ultrapassar a tese metafísica que opõe o ser ao devir. E ela o faz declarando que o revir é o ser do devir. Por que é necessária uma tal afirmação? Deleuze argumenta que o eterno retorno deve ser pensado como uma resposta ao problema da passagem do tempo. Mas ele formula e responde esse problema sob uma inspiração bergsoniana que aproxima, nesse tema específico, Nietzsche e Bergson:

Se o presente não passasse por ele mesmo, se fosse preciso esperar um

novo presente para que este se tornasse passado, nunca o passado em 
geral se constituiria no tempo, nem esse presente passaria; não podemos esperar, é preciso que o instante seja ao mesmo tempo presente e passado, presente e futuro para que ele passe (e passe em proveito de outros instantes). É preciso que o presente coexista consigo mesmo como passado e como futuro. É a relação sintética do instante consigo mesmo como presente, passado e futuro que funda sua relação com outros instantes (DELEUZE, 1976, p. 25).

Após estabelecer essa correlação do eterno retorno em Nietzsche com o problema da passagem do tempo em Bergson, Deleuze argumenta que, em função desse seu aspecto sintético, o eterno retorno em Nietzsche não pode ser compreendido como eterno retorno do mesmo. O um que retorna se diz do devir, da diferença que retorna como síntese: "síntese do tempo e de suas dimensões, síntese do diverso e de sua reprodução, síntese do devir e do ser afirmado do devir, síntese da dupla afirmação." Por isso, o eterno retorno exige um outro princípio que não o da identidade. Esse novo princípio, apresentado como a razão suficiente do diverso e de sua reprodução, da diferença e de sua repetição, segundo a análise de Deleuze, é definido por Nietzsche com o conceito de vontade de potência.

A vontade de potência diz respeito ao conceito de força; mostrandose, simultaneamente, um complemento da força e algo interno à força, ela é princípio intensivo para a síntese das forças, de sua diferença e de sua reprodução. O conceito de vontade de potência é apresentado como princípio diferencial e genético da experiência real. Como compreender a vontade de potência como princípio? Como o conceito de vontade de potência afeta e redefine o conceito de princípio? De que modo Deleuze interpreta a vontade de potência para fazer dela um principio imanente, diferencial e genético, da experiência real?

Em primeiro lugar, insiste na novidade do conceito de vontade de potência: com ele a potência deixa de ser objeto de uma representação e a vontade não almeja medir-se pelos valores dominantes. Assim compreendido, esse conceito não configura um conflito entre vontades, nem a guerra como meio de atribuir à vontade os valores estabelecidos. Com ele a potência se diz da vontade e a vontade torna-se criadora e diferenciadora nos seus efeitos. Mais ainda: se a vontade de potência torna 


\section{4}

impensável um equilíbrio entre as forças em relação, compreende-se então que esse novo princípio não possa ser geral, isto é, ser mais amplo do que aquilo de que é princípio. Se a vontade de potência não é um princípio geral é porque ela é um princípio plástico e em metamorfose, nunca superior às determinações que opera.

Nisto não há nenhum contrassenso, uma vez que a vontade de potência não é um princípio que negue o acaso; como diz Deleuze, ela é o que o acaso comporta como princípio. Como princípio que afirma o acaso, a vontade de potência garante uma dupla gênese: a gênese recíproca das diferenças de quantidades das forças (dominantes ou dominadas) e a gênese absoluta das qualidades das forças em questão (ativas ou reativas). Mesmo assim, insiste Deleuze, não se pode confundir o querer com as forças, nem a elas reduzi-lo, sob pena de que, com o desaparecimento de sua diferença, perca-se a inteligibilidade (o sentido e o valor) das forças em relação. Tal princípio é plástico, porque a vontade de potência é qualificada na relação das forças que ela motiva seja como afirmativa seja como negativa.

Como compreender a possibilidade da metamorfose da vontade de potência? É certo que existe uma dinâmica das forças que torna possível um devir das forças. Mas como o dinamismo das forças articula-se com a vontade de potência, como pode o dinamismo das forças afetar o seu princípio? Deleuze esclarece esse problema aproximando Nietzsche de Espinosa: a relação das forças é diferenciada na medida em que uma é afetada por outras, a vontade de potência manifesta-se como o poder determinado da força de ser ela própria afetada. Este poder não envolve necessariamente passividade, mas sensibilidade. Por essa razão, a vontade de potência pode apresentar um duplo aspecto: "determina a relação das forças entre si, do ponto de vista da gênese e da produção das forças, mas é determinada pelas forças em relação, do ponto de vista de sua própria manifestação.” (DELEUZE, 1962, p.70).

Resta ainda, entretanto, um outro aspecto da questão: como a vontade de potência pode tornar-se negativa? Ainda uma vez esta possibilidade depende da dinâmica das forças. No caso, depende de que esta dinâmica afete as qualidades das forças e constitua um devir reativo das forças ativas. Deleuze explica essa possibilidade com a seguinte consideração: "A força reativa, mesmo quando obedece, limita a força ativa, impõe-lhe limitações 
e restrições parciais, já está possuída pelo espírito do negativo." (DELEUZE, 1962, p.63). E acrescenta que, se com a ajuda de circunstâncias internas ou externas, as forças reativas neutralizam as forças ativas, haverá o triunfo das forças reativas. Com esse triunfo ocorre uma efetiva inversão dos valores.

É a vitória das forças reativas, o desenvolvimento do niilismo, que define, segundo a interpretação deleuziana de Nietzsche, o sentido histórico da cultura. E é a partir desta avaliação, como crítica ao niilismo, que a definição do segundo aspecto do eterno retorno - como pensamento ético e seletivo - assume, na interpretação de Deleuze, sua importância fundamental. Pois o que está em questão nesta interpretação é a possibilidade de um pensamento afirmativo e seletivo que certifique a atividade da força e a afirmação da vontade.

Deleuze distingue, portanto, no pensamento do eterno retorno, dois sentidos da seleção: por um lado, o pensamento do eterno retorno formula uma regra prática para a vontade ("o que tu quiseres, quere-o de tal modo que também queiras o seu eterno retorno") que, ao eliminar do querer tudo o que cai fora do eterno retorno, faz da vontade uma criação; por outro lado, o pensamento do eterno retorno da diferença combate o niilismo, porque faz da negação a negação das forças reativas. Deleuze esclarece: "No voltar-se contra si, processo da reação, a força ativa torna-se reativa. $\mathrm{Na}$ autodestruição as próprias forças reativas são negadas e conduzidas ao nada. Por isso diz-se que a autodestruição é uma operação ativa, uma 'destruição ativa'” (DELEUZE, 1962, p.79). Há, então, uma dupla seleção no eterno retorno: a primeira elimina da vontade o que não suporta a prova seletiva do seu eterno retorno; a segunda faz entrar no ser, pelo pensamento do eterno retorno, o que nele não pode entrar sem mudar de natureza. "Não se trata mais de um pensamento seletivo, mas sim do ser seletivo, pois o eterno retorno é o ser e o ser é seleção (seleção = hierarquia)" (DELEUZE, 1962, p.80).

Como compreender essa afirmação de um ser seletivo, essa equação ser $=$ seleção? A conexão dos dois sentidos do eterno retorno esclarece, em parte, o problema da seleção, pois, como doutrina física e cosmológica, o eterno retorno afirma o devir. Contudo, como ressalta a interpretação de Deleuze, o devir é duplo: há um devir reativo das forças ativas quando separadas do que podem pelas ficções reativas — e há um devir 
ativo das forças reativas. É exatamente este o problema do eterno retorno da diferença como pensamento ético e seletivo: o da possibilidade do devir ativo das forças reativas. Sua afirmação envolve uma seleção que expulsa do pensamento as ficções que separam as forças ativas do que elas podem. A primeira seleção elimina da vontade, pelo pensamento do eterno retorno, os semiquereres que a separam de toda sua potência. $O$ que se constitui com isso? A identidade da vontade com a criação. A segunda seleção elimina, pelo pensamento do eterno retorno, a perspectiva que instaura as ficções, isto é, a negação. O que é que com isso se constitui? A afirmação da identidade do ser com o devir ativo.

Se o eterno retorno como doutrina física afirma o ser do devir, enquanto ontologia seletiva ele afirma o ser do devir como 'afirmandose' do devir-ativo. Conclui Deleuze: “A fórmula completa da afirmação é: o todo, sim, o ser universal, sim, mas o ser universal se diz de um só devir, o todo se diz de um só momento" (DELEUZE, 1962, p.81-82). Do primeiro ao segundo sentido do eterno retorno, passa-se, portanto, da afirmação do devir à seleção do devir ativo: passa-se do ser do devir ao ser do devir ativo.

\section{0 problema ontológico na interpretação do eterno retorno}

Permanece ainda uma dificuldade: como pensar a diferença estabelecida entre as duas seleções, entre um pensamento seletivo e um ser seletivo? $\mathrm{O}$ fundamental, nesta questão, é não substancializar o ser, não pensá-lo como um fato, isto é, como ordem dada ou mesmo como princípio de ordenação de um todo dado. O ser seletivo resulta de uma doutrina ética que afirma e dá valor de ser apenas ao devir ativo. Ora, uma ontologia seletiva é ainda um pensamento, o ser seletivo é um conceito criado que enuncia um pensamento do ser como afirmação do devir ativo. Assim, as duas seleções são operações do pensamento: na primeira, o pensamento retira de si os pensamentos reativos; na segunda, o pensamento subtrai de si a perspectiva reativa, elimina a negação como perspectiva de avaliação. O pensamento, tornado pura afirmação, transmuta a negação em negação das forças reativas. Ou seja, o pensamento que conquista sua imanência torna-se pura afirmação (afirmação da afirmação). Com esse movimento, 
o pensamento torna-se criador: constitui-se como afirmador do ser, do ser seletivo que só se diz do devir ativo.

É fundamental aqui compreender que a equação "ser = seleção" fazse acompanhar desta outra equação: "seleção = hierarquia". Sabendo-se que o conceito de hierarquia refere-se ao conceito de valor e que este diz respeito não às realidades objetivas, mas às diferenças de qualidade da vontade, deve-se dizer que é a segunda equação que encerra o segredo da primeira, isto é, que o ser é perspectiva e que ele, enquanto ato seletivo, aprova o que se afirma como perspectiva e não o que se pretende fato. Mas, por outro lado, é fundamental lembrar que as perspectivas atualizam-se em modos de vida, e, assim, o que o pensamento do eterno retorno seleciona, ao selecionar o devir ativo, são maneiras de viver. Entretanto, não se devem confundir modos de vida, valores, com realidades: os primeiros são da ordem do pensamento, as segundas são do domínio da objetividade ou dos estados de coisas. É esta distinção que impede a identificação ou a redução do pensamento do eterno retorno a uma moral, uma vez que o que retorna não são os valores estabelecidos, concebidos como realidades em si, mas o pensamento enquanto afirmação avaliadora e criadora.

É, portanto, a subtração da perspectiva moralista e realista - que necessariamente nega a si própria enquanto perspectiva - que dá sentido à equação "ser = seleção". Pois essa fórmula não significa apenas que a vida não pode ser avaliada por um valor transcendente e que as maneiras de viver possuem o valor de suas perspectivas; significa, sobretudo, a afirmação do pensamento e do ser como perspectiva. Desse modo, a seleção do eterno retorno não apenas se distingue da moral; é ela que revela que a moral tem um começo e que, na sua origem, ela é uma perspectiva que se nega e que, ao negar-se enquanto tal, não apenas assume a negação enquanto princípio como reivindica ser a expressão de um universal abstrato.

Finalmente, o que se seleciona é a afirmação da afirmação, que envolve a afirmação da diferença em todas as suas variantes, como acaso, multiplicidade e devir. Essa seleção evidencia a contradição do devir reativo das forças com o ser do devir. Tal contradição se explica porque as forças reativas sustentam pensamentos e modos de vida que se negam como perspectiva e arvoram sua pretensão à universalidade. São, portan- 
to, o negativo como qualidade da vontade e a vitória das forças reativas no pensamento que sustentam o compromisso da Filosofia da Representação com a santificação dos valores vigentes.

Se o devir ativo se diz das forças ativas e se estas são pensamentos afirmativos, retorna a questão: o que é um tal pensamento, ou o que é pensar quando o pensamento perde a referência do todo e a da sua própria unidade? Mais ainda: o que se torna o pensamento quando ele passa pela prova do seu eterno retorno? Deleuze, num primeiro momento, responde: um pensamento sem imagem.

Mas poderá a crítica conquistar tal imanência? Como já se viu, Deleuze encontra em Nietzsche, no conceito de vontade de potência, o princípio de uma tal crítica imanente, a condição de um pensamento sem imagem. O duplo aspecto da seleção no pensamento do eterno retorno revela um movimento que vai da seleção dos pensamentos ativos à seleção da vontade de potência afirmativa. Neste sentido, deve-se sublinhar a dupla função do conceito de vontade de potência: por um lado, como princípio da diferença e de sua repetição, a vontade de potência é apresentada por Deleuze como princípio do qual depende o eterno retorno como doutrina cosmológica e física; por outro lado, o eterno retorno, como pensamento ético, ao selecionar a repetição da diferença, afirma o ser do devir e, no mesmo movimento, corrobora a afirmação como qualidade da vontade de potência. Por essas razões, Deleuze considera que, à questão crítica "Quem?", corresponde, como princípio crítico, o conceito de vontade de potência e, como movimento crítico, o eterno retorno como pensamento ético e seletivo. Que operações as afirmações de tal princípio e de tal movimento tornam possíveis no domínio do pensamento?

Antes de ir adiante com essa discussão, é necessário voltar, após a investigação da interpretação deleuziana da doutrina do eterno retorno, à questão: o que uma pura afirmação envolve? Uma afirmação pura é produção e criação. Contudo, é preciso salientar que, desse novo ponto de vista, embora ela exclua a negação como potência autônoma ou como qualidade primeira, nem por isso separa-se de uma agressividade que resulta da redefinição da negação - agora subordinada ao elemento da afirmação - e de sua função crítica.

A afirmação pura é a transvaloração que a doutrina do eterno retorno conquista. Ela é a nova qualidade da vontade de potência, efeito da 
subtração da negação como princípio de avaliação dos valores. Assim, a transvaloração significa que os valores não derivam mais do negativo, que estes, não sendo postos como superiores à vida, não mais a depreciam. No entanto, como já foi dito, se a negação deixa de ser princípio de avaliação, ela, contudo, não sucumbe no vazio e desaparece do pensamento. Ao contrário, Deleuze enfatiza, na sua análise da transvaloração nietzschiana, a interligação dos seguintes movimentos que se associam ao advento da afirmação como princípio de avaliação: 1. Uma mudança da imagem do pensamento: o pensamento submetido à razão ou à vontade de conhecimento apreende, necessariamente, a vontade como potência de negação, e, por outro lado, só a vontade de potência negativa sustenta uma vontade de conhecer. O afastamento do ideal de conhecimento é correlato de um pensamento afirmativo e da mudança na qualidade da vontade de potência; 2. A negação, desde então, subordina-se à afirmação e muda de sentido, tornando-se potência de afirmar: "A negação não é mais a forma sob a qual a vida conserva tudo o que é reativo nela, mas, ao contrário, a ato pelo qual ela sacrifica todas as suas formas reativas" (DELEUZE, 1962, p.202). Com a subordinação da negação à afirmação, só a afirmação subsiste enquanto potência independente. 4. Desse modo, a negação, como consequência da potência de afirmar, é o aspecto crítico que subtrai, no pensamento da existência, todos os valores transcendentes ao pensamento e à vida. 5. Conferindo um novo sentido à negação, a afirmação se diz de um devir ativo universal.

Mas esse outro jogo da afirmação e da negação fica sem sentido se ele não é apreendido como decorrência de uma afirmação seletiva primeira: a subtração, consequência da afirmação da afirmação, do negativo como potência autônoma de interpretação. Isto porque a autonomia da negação ou a negação como princípio é, na interpretação que Deleuze faz da crítica nietzschiana, o foro genealógico de todas as ficções que depreciam a vida ${ }^{2}$.

Deleuze retoma a crítica ao negativo retomando a distinção assinalada por Nietzsche entre dois tipos de afirmação: uma não sabe, efetivamente, nem afirmar nem negar, porque afirma tudo o que a perspectiva negativa põe como real e verdadeiro; a outra modalidade de afirmação eleva-se à potência criadora incorporando a negação, mas redefinida e subordinada à potência da afirmação pura. Isto significa, para Deleuze, que a afirmação não se opõe à negação, mas difere desta, libertando a negação da perspec- 
tiva negativa, negação do negativo na vontade de potência. A afirmação do Asno aprova e suporta todos os valores superiores; a afirmação criadora seleciona a diferença e elimina tudo o que pode ser negado ao afirmar a própria afirmação. A primeira é expressão do niilismo: suporta e afirma o "ser", o "verdadeiro" e o "real"; a segunda propõe uma nova ontologia, que afirma a afirmação como ser: "O ser não é objeto de afirmação, nem um elemento que se daria em apoio à afirmação. A afirmação não é potência do ser, ao contrário. A própria afirmação é o ser; o ser é somente a afirmação em toda a sua potência." (DELEUZE, 1962, p.213).

Deleuze compreende a dinâmica que eleva a afirmação a sua mais alta potência como movimento de reduplicação da afirmação:"É a afirmação primeira (o devir) que é ser, mas ela só o é como objeto de uma segunda afirmação. As duas afirmações constituem a potência de afirmar em seu conjunto" (DELEUZE, 1962, p.214). Mas é fundamental ainda mostrar como a lógica que afirma o devir se articula com a lógica da dupla afirmação, que afirma o ser do devir.

\section{0 estatuto da afirmação ontológica}

Como já foi visto, o movimento da seleção significa a eliminação das transcendências pressupostas pelo pensamento quando este é constituído por uma vontade de potência negativa. Mas por que há a necessidade de uma dupla afirmação para que a potência de afirmar se institua?

O essencial, neste caso, para uma filosofia como a de Deleuze que almeja dar consistência à ideia de que o pensamento seja criador, é assegurar que a afirmação primeira não seja uma constatação, no caso a constatação do devir como um dado. Portanto, pode-se sugerir a hipótese de que a função da afirmação segunda ou reduplicada seja a de revelar que a afirmação primeira já comporta uma dimensão ética que a compromete com a elaboração de um pensamento capaz de pensar a passagem do tempo, capaz de conceber uma síntese do tempo como devir, pela qual o presente torna-se passagem, quando contraído num instante que se bifurca em passado e futuro. A afirmação segunda, enquanto afirmação da afirmação, impede, desse modo, a ilusão de suporse uma subordinação da afirmação a um dado, mesmo que o dado seja 
concebido, por contrassenso, como sendo o devir. Quanto a isto, Deleuze é incisivo: "Nietzsche critica toda concepção da afirmação que faria desta uma simples função, função do ser ou do que é. Como quer que seja concebido esse ser: como verdadeiro ou como real, como númeno ou como fenômeno. Como quer que seja concebida essa função: como desenvolvimento, exposição, desvelamento, revelação, realização, tomada de consciência ou conhecimento" (DELEUZE, 1962, p.209). A afirmação segunda tem, pois, o sentido de eliminar todos os pressupostos: recusa a submissão do pensamento a um foro originário ou a um estado de coisas atual, ou mesmo a uma orientação teleológica.

Com esta interpretação do sentido da afirmação, Deleuze se afasta de toda posição realista na filosofia e propõe uma nova ontologia, um construtivismo que faz da diferença a essência do afirmativo e que diz que, no pensamento e na vida, só possui valor de ser a afirmação que se afirma enquanto tal. Do ponto de vista dessa nova ontologia "não há verdade do mundo pensado nem realidade do mundo sensível, tudo é avaliação, mesmo e, sobretudo, o sensível e o real" (DELEUZE, 1962, p.211-212). O que resulta nas seguintes afirmações que se encadeiam: o mundo é vivo; e o mundo vivo é vontade de potência; e viver é avaliar.

Qual é o jogo da diferença nesta afirmação e o que afirma uma tal afirmação? Deleuze esclarece:

A afirmação é posta uma primeira vez como o múltiplo, o devir e o acaso. Pois o múltiplo é a diferença entre o um e o outro, o devir é a diferença consigo mesmo, o acaso é a diferença 'entre todos' ou distributiva. Em seguida a afirmação se desdobra, a diferença é refletida na afirmação da afirmação: momento da reflexão no qual uma segunda afirmação toma por objeto a primeira. Mas assim a afirmação se duplica: como objeto da segunda afirmação, ela é a afirmação ela própria afirmada, a afirmação reduplicada, a diferença elevada à sua mais elevada potência. O devir é o ser, o múltiplo é o um, o acaso é a necessidade (DELEUZE, 1962, p.217).

Se esta reduplicação da afirmação é preparada pela diferenciação da negação que a afirmação promove e exige, podendo-se compreendê-la como a necessária potencialização da afirmação que a distingue de uma simples recognição, resta ainda saber: o que mobiliza a diferença 
na afirmação? Ou, para falar em linguagem nietzschiana: que vontade deseja a potencialização da afirmação? Deleuze completa: "É a vontade de potência como elemento diferencial que produz e desenvolve a diferença na afirmação, que reflete a diferença na afirmação da afirmação, que a faz retornar na afirmação ela mesma afirmada." (DELEUZE, 1962, p.217). Se, com já se disse, a vontade de potência é, na interpretação deleuziana de Nietzsche, o princípio de uma crítica verdadeiramente imanente, então se deve concluir que esta crítica incide sobre tudo o que exprime a vontade de potência negativa e sobre a própria qualidade da vontade de potência: a supressão da negação enquanto princípio autônomo de interpretação e de avaliação permite a negação da vontade de potência negativa e, assim, sua metamorfose em vontade de potência afirmativa. E, em outra dimensão do mesmo movimento crítico, a dupla afirmação que constitui a vontade de potência afirmativa introduz a diferença na afirmação e faz da vontade de potência o princípio plástico de uma crítica imanente, ao mesmo tempo seletiva e criadora.

A questão do estatuto da negação quando integrada no movimento da afirmação pura e o problema da identidade da afirmação com a diferença retornam em Diferença e repetição, integrados à problemática ontológica que Deleuze circunscreve, precisando e aprofundando sua interpretação do eterno retorno com a sua tese que afirma a univocidade do ser. Quanto ao estatuto da negação, Deleuze, ao criticar a filosofia da representação, diz que a filosofia da diferença recusa a alternativa geral da representação infinita:

"ou o indeterminado, o indiferente, o indiferenciado, ou então uma diferença já determinada como negação, implicando e envolvendo o negativo (assim a filosofia da diferença recusa, também, a alternativa particular: negativo de limitação ou negativo de oposição). Em sua essência, a diferença é objeto de afirmação, ela própria é afirmação. Em sua essência, a afirmação é, ela própria, diferença” (DELEUZE, 1968, p.74).

Mas em que sentido a afirmação já é diferença? E ainda: como uma afirmação diferencial comporta uma potência destrutiva irredutível ao negativo? 
Estas questões se articulam de modo necessário. É preciso, aqui, considerar a hipótese de que a filosofia da diferença se constrói procedendo por seleção criativa. Todavia, é fundamental sublinhar que esse procedimento também dá conta do modo de construção dos problemas e do sentido dos conceitos dessa filosofia. Assim, pode-se dizer que os conceitos de afirmação diferencial e de vontade de potência não decorrem só de retificações operadas no campo filosófico. Como já foi mencionado, o conceito de vontade de potência tem como correlatas as subtrações de uma série de componentes conceituais que acompanham os conceitos metafísicos de vontade. $\mathrm{O}$ mesmo pode ser dito da afirmação diferencial: este conceito supõe e implica a subtração de uma série de componentes que acompanham o conceito de afirmação quando este é subordinado ao ideal do conhecimento, quando é integrado a uma ontologia que supõe a preexistência do ser e se orienta pela ideia de verdade. É justamente por esses conceitos - vontade de potência e afirmação diferencial - não se separarem das gêneses seletivas que eles podem funcionar como princípios críticos que dão validade e necessidade aos movimentos criadores envolvidos na prova do eterno retorno.

Uma afirmação pura, diferencial, é um ato que suprime pressupostos e, ao mesmo tempo, constrói a ideia mesma de perspectiva. Desse modo, o componente diferencial é que faculta ao conceito de afirmação implicar uma agressividade e uma destruição não derivadas da negatividade, não acionadas pelo negativo. A plena compreensão dessa possibilidade depende da teoria de uma dialética diferencial, objeto do capítulo "Síntese ideal da diferença" do livro Diferença e repetição. Em todo caso, ainda a título de introdução, deve-se lembrar, mais uma vez, que diferencial diz respeito a um cálculo que procede por subtrações de constantes, cálculo que permite construir ideias diferenciais e pensar universais que não se opõem ao singular e à diferença, pois que só se atualizam, concretamente, como diferenças singulares. No que se refere à questão presente, contudo, é preciso dizer que diferencial diz respeito ao processo de subtração das ficções que submetem o pensamento ao negativo e que produzem uma imagem do pensamento cujos pressupostos configuram tanto uma unidade subjetiva para o pensamento quanto uma ordem objetiva para o mundo. É, portanto, do ponto de vista de uma afirmação diferencial que Deleuze pode distinguir 
duas maneiras de invocar 'destruições necessárias': a do poeta que fala em nome de uma potência criadora, apto a reverter todas as ordens e todas as representações, para afirmar a Diferença no estado de revolução permanente do eterno retorno; e a do político, que se preocupa, antes de tudo, em negar o que 'difere' para conservar, prolongar, uma ordem estabelecida na história ou para estabelecer uma ordem histórica que já solicita no mundo as formas de sua representação (DELEUZE, 1968, p.75).

Esta distinção repercute na distinção de dois tipos de seleção: uma derivada de um começo na negação, dirigida por um "não" inicial, e outra derivada de uma afirmação, orientada por um "sim" inicial. O primeiro tipo de seleção começa por um "não" e só é capaz de produzir um fantasma ou arremedo de afirmação. O segundo tipo se constitui a partir de uma afirmação primeira, sendo sua agressividade o resultado desta afirmação e sua negação um epifenômeno do "sim". Deleuze reafirma esse pensamento ao retomar, em Diferença e repetição, a sua interpretação do eterno retorno:

Que haja uma gênese da afirmação como tal é o que nos escapa toda vez que deixamos a afirmação no indeterminado ou toda vez que colocamos a determinação no negativo. A negação resulta da afirmação: isto quer dizer que a negação surge em consequência da afirmação ou ao lado dela, mas somente como a sombra de um elemento genético mais profundo - desta potência ou desta 'vontade' que engendra a afirmação e a diferença na afirmação. Os que carregam o negativo não sabem o que fazem: tomam a sombra pela realidade, nutrem fantasmas, separam a consequência das premissas, dão ao epifenômeno o valor do fenômeno e da essência (DELEUZE, 1968, p.78).

A gênese da afirmação remete ao movimento do eterno retorno que seleciona a vontade de potência afirmativa enquanto princípio da experiência real. Mas não se pode pensar a gênese da experiência real sem passar pela subtração do conjunto dos pressupostos que organizam a filosofia da representação. No momento, para melhor compreender a lógica que comanda essas subtrações, é preciso esclarecer o sentido do conceito de diferença que se compõe com o conceito de afirmação. É 
preciso, inicialmente, ressaltar que também o conceito de diferença decorre de uma afirmação seletiva e criativa; no caso, de um conjunto de subtrações que desfiguram a filosofia da representação.

\section{Gênese da afirmação e gênese da diferença}

Segundo Deleuze, não é multiplicando as representações e os pontos de vista que se atinge a diferença, pois esta, no âmbito da representação, permanece sempre subordinada à identidade. É preciso encontrar, não propriamente a identidade da coisa com o ponto de vista, mas o pertencimento da coisa ao ponto de vista. Como se conquista esse perspectivismo radical, que afirma não a relatividade da verdade mas a verdade do relativo? É necessária uma subversão da imagem dogmática do pensamento que permita um novo conceito de diferença suscetível de recusar tanto a identidade do objeto visto quanto a do sujeito que ocupa o ponto de vista, de tal modo que: "Cada coisa, cada ser deve ver sua identidade tragada pela diferença, cada qual sendo só uma diferença entre diferenças. É preciso mostrar a diferença diferindo" (DELEUZE, p.1968, p.91).

A leitura atenta desta citação revela que a gênese da afirmação se confunde com a gênese da diferença. Pois, a rigor, não há uma diferença dada a ser afirmada: a diferença é conquistada por uma "deformação da representação", por um "esquartejamento da coisa". Se desse modo, porém, não há mais identidade das coisas (A é A), nem identidade do sujeito $(\mathrm{Eu}=\mathrm{Eu})$, o pensamento deve conquistar, por diferenciação, uma afirmação da unidade da coisa com o ponto de vista, isto é, um perspectivismo.

Deleuze retoma, assim, através de Nietzsche, duas intenções da crítica kantiana: o projeto de uma crítica imanente e a ideia da filosofia como legisladora enquanto filosofia. No entanto, Deleuze considera, também com Nietzsche, que a imanência e o ideal do filósofo legislador, almejados pela crítica kantiana, fracassam, já de saída, pela concepção mesma desta crítica:

Kant não fez senão levar ao extremo uma concepção muito velha da crítica. Ele concebeu a crítica como uma força que deveria incidir sobre todas as pretensões ao conhecimento e à verdade, mas não sobre 
o próprio conhecimento, não sobre a própria verdade. Como uma força que deveria incidir sobre todas as pretensões à moralidade, mas não sobre a própria moral. Desse modo, a crítica total transforma-se em uma política de compromisso (DELEUZE, 1962, p.102).

A transcendência da Verdade e da Moral, evidentemente, compromete, como se verá, a intenção de uma legislação filosófica imanente. Mais ainda: a imanência fica também corrompida pela incapacidade da crítica kantiana de ater-se interna à razão sem evitar o contrassenso de instituir um tribunal no qual a razão figura como juiz e como réu. A imanência também fica corrompida pela impotência da filosofia transcendental em dar conta da gênese da experiência real, contentando-se com condições que permanecem exteriores ao condicionado.

\section{A teoria diferencial do pensamento e da experiência}

Diferença e repetição - livro no qual pela primeira vez Deleuze dedica-se, por sua conta, a construir problemas e a criar conceitos - é dominado pelo signo do Eterno Retorno da Diferença, a começar pelo título que entrelaça esses dois conceitos, fazendo um passar no outro. Com essa observação, queremos indicar que este livro retoma a interpretação do Eterno Retorno, exposta em Nietzsche e a filosofia, para dela extrair uma filosofia da Diferença e da Repetição. Essa filosofia não pretende dar novo brilho a uma diferença conceitual, mas criar um conceito de diferença nela mesma; do mesmo modo, não busca aprimorar a ideia de repetição como uma diferença sem conceito (diz-se que há repetição toda vez que duas coisas ou mais diferem tendo o mesmo conceito), mas um conceito da repetição nela mesma. O problema é criar esses novos conceitos para assegurar que diferença e repetição liberem-se de suas subordinações ao idêntico, ao semelhante, ao análogo, ao oposto. Não se pode libertar as potências próprias da diferença e da repetição sem questionar a imagem do pensamento que sustenta tais subordinações da diferença e da repetição.

Nesta tarefa está a importância do capítulo "A imagem do pensamento", em que Deleuze discerne os pressupostos implícitos que compõem, 
segundo suas denominações, a "imagem dogmática do pensamento", a sustentar a "fillosofia da representação". Esta imagem pressupõe que o pensamento tem uma natureza e o pensador uma boa vontade; toma como modelo a recognição e como forma o senso comum que postula a concordância, com respeito a um objeto suposto o mesmo, de todas as faculdades - sensibilidade, memória, imaginação, entendimento, pensamento, etc. - bem como a integração dessas faculdades na unidade de um sujeito idêntico a si; considera o erro o inimigo do pensamento; supõe que o verdadeiro concerne às soluções e não aos problemas como tais. A crítica a esses pressupostos, do nosso ponto de vista, é orientada pela ideia do eterno retorno da diferença: essa critica torna indissociável crítica e criação. Ao submeter o pensamento ao crivo do eterno retorno da diferença, Deleuze extrai do questionamento da imagem dogmática do pensamento novas orientações, que introduzem a diferença e a repetição no âmago do pensamento.

Deleuze faz questão de manter o conceito de transcendental, mas o faz isolando-o do seu contexto kantiano, libertando-o dos pressupostos implícitos da representação e recusando-se a decalcá-lo da forma da doxa. Esta operação relança o conceito de transcendental em uma nova cena, em um novo plano de imanência. Numa palavra, a teoria diferencial e genética da experiência recusa a imagem do transcendental implicada na representação.

Neste novo plano, fulgura a questão da gênese do pensar no pensamento. A partir dela, Deleuze elabora uma teoria diferencial das faculdades que introduz as manifestações da diferença - o acaso, o devir e a multiplicidade - no cerne do pensamento. Com ela tudo começa por um choque na sensibilidade, não por recognição. É sempre pela afirmação de um encontro, fortuito e involuntário, com um objeto portador de problema que emerge do fundo do tempo que o pensamento nasce e se desdobra em múltiplas durações. O objeto do encontro é signo de um acontecimento que transtorna as coordenadas da experiência corrente. É a questão suscitada pelo encontro com um signo que, quando afirmada, estimula a criação de novas maneiras de sentir e de pensar e descarta qualquer resposta que não suporte o eterno retorno da questão.

Deleuze distingue dois regimes de exercício do pensamento: um dito empírico, outro denominado transcendente. O pensamento, com efeito, 
começa verdadeiramente com a passagem de um regime ao outro. O que caracteriza cada regime? O primeiro é expressão do poder da imagem dogmática do pensamento, o segundo expressa a potência de uma nova imagem do pensamento, um pensamento sem imagem. $O$ exercício empírico do pensamento funciona sob o modelo da recognição e do senso comum, o regime transcendente introduz diferença e a repetição no pensamento e ultrapassa os limites da representação.

Se a unidade do sujeito e a identidade do objeto são constantes pressupostas, enquanto tais, pelo exercício empírico do pensamento, a subtração dessas constantes é efetivamente essencial para a constituição do novo campo transcendental. Com esse procedimento o pensamento escapa de sua submissão a um estado de coisas ao mesmo tempo em que se liberta de pressupostos que o mobilizavam para não pensar. A teoria diferencial da experiência é, antes de tudo, uma teoria genética da experiência real e do pensar como processo de criação. Elabora-se simultaneamente como crítica à metafísica do conceito ou das essências transcendentes e como crítica à crítica kantiana da metafísica, que estabelece o campo transcendental como instância de condicionamento da experiência possível. Com ela o pensamento não mais possui formas e regras a priori que lhe assegurariam a possibilidade de determinar condições de possibilidade da experiência.

Observa-se assim uma alteração de sentido do conceito de campo transcendental: seu problema não é mais o do condicionamento da experiência possível, mas o da gênese do pensar no pensamento. Ao enunciar assim o problema, Deleuze introduz o devir do pensamento como tema transcendental que põe a prova do eterno retorno no âmago da experiência real. A experiência inclui, portanto, necessariamente, uma dimensão ética que envolve a afirmação de um exercício superior do pensamento: forçada por um encontro fortuito e involuntário, cada faculdade submetida à violência do seu encontro próprio deve ir ao limite de sua potência para ali enfrentar a prova do seu devir, a sua diferença e imanência radical.

Como compreender a ideia de que o pensamento começa com a violência de um encontro? O que é um encontro? Em que medida ele é, necessariamente, violento? Finalmente, por que só ele impõe uma necessidade, não hipotética, ao pensamento? 
O objeto de um encontro deve ter a potência de violentar a concórdia das faculdades característica do senso comum e a identidade do sujeito e do objeto, postulada pelo modelo da recognição. A primeira característica deste objeto problemático é a de não possuir a identidade que lhe permitiria ser representado nem reconhecido por qualquer faculdade, o que força cada faculdade a ir até o seu limite e afirmar o seu objeto próprio. É importante ressaltar que é apenas a sensibilidade que se encontra com o seu objeto próprio, todas as demais faculdades conquistam seus respectivos objetos como efeito da violência desse encontro da sensibilidade com o que só pode ser sentido. Ser paradoxal é a segunda característica do objeto de um encontro. É um objeto paradoxal, na medida em que é simultaneamente o que não pode ser apreendido no exercício empírico de cada faculdade e o próprio de cada faculdade quando conquista seu exercício superior. Esta característica explica seu componente violento: propõe a cada faculdade uma prova, a prova do seu devir. Se afirmado, cada faculdade conhece sua metamorfose singular, uma mudança de regime e a descoberta de seu objeto próprio. Com a conquista de sua potência, as faculdades transcendem seu exercício empírico e, no seu exercício superior, chegam a afirmação do ser do seu devir.

A experiência real, como já se disse, começa com o encontro da sensibilidade com sua diferença, a intensidade, sua questão: o que é sentir? Esse acontecimento transtorna o senso comum pois o que a sensibilidade apresenta às demais faculdades é o enigma de sua perturbação mesma, que se alastra fustigando as outras faculdades. A memória, violentada por uma sensação questionante que não lhe concerne, vai ao seu limite engendrando seu objeto próprio (o imemorial) e sua questão exclusiva (o que é lembrar?). Desta vez é ela quem violenta o pensamento que desperta do seu exercício empírico e então encontra seu objeto imanente (a Essência, o ser do inteligível) e sua questão (o que é pensar, quando pensar não é representar ou julgar). Assim, a diferença na sensação, a diferença na memória, a diferença no pensamento, ao ressoarem em sínteses disjuntivas, traçam um plano de imanência, plano efetivamente transcendental, constituído apenas por diferenças de potencial, intensivas, diferenciais, virtuais. É nesse plano, que não é dado, mas intensamente traçado, que pode nascer o pensar no pensamento. 
É importante aqui salientar que Deleuze emprega a mesma imagem ("sair dos eixos") para dar conta tanto da gênese do pensamento no pensamento, quanto para caracterizar a reversão da relação do tempo com o movimento e, em especial, para pensar a terceira síntese do tempo, a síntese do tempo como futuro, que permite à repetição dizer-se da diferença. Nos dois casos, com a teoria diferencial das faculdades e com a teoria da terceira síntese do tempo, Deleuze enfrenta o problema de uma seleção criativa e de uma criação seletiva. Em ambos os casos, o pensamento é forçado a ir ao seu limite, é levado à prova de seu eterno retorno. A rigor, não se trata de uma analogia entre os dois processos, pois um passa no outro.

O conceito de repetição é essencial no desenvolvimento de uma teoria do tempo apropriada à afirmação do eterno retorno da diferença. Com ele a repetição diferencia-se distinguindo três sínteses do tempo, três dimensões da multiplicidade temporal: uma síntese do tempo como presente, institui o plano do presente, a temporalidade do Habitus como fundação do tempo; a síntese do tempo como passado, institui o volume do passado, Memória como fundamento do tempo; e a síntese do tempo com futuro, estabelece a amplitude do futuro, a temporalidade do devir como afundamento do presente e do passado.

Deleuze aproxima a terceira síntese do tempo do tempo trágico de Hölderlin, diferenciado em um Antes e um Depois de um Acontecimento único e formidável. A temporalidade própria ao tempo com futuro admite uma Ordem, um Conjunto e uma Série do tempo.

A ordem do tempo assegura uma distribuição puramente formal do desigual em função de uma cesura. Distingue-se um passado e um futuro referidos ao acontecimento como instante da cesura. A ideia do conjunto do tempo compreende a cesura como acontecimento que deve ser determinado na imagem de uma ação formidável, adequada à imensidão do tempo. A série do tempo se define da duração em três dimensões: o passado é o tempo no qual a ação é sentida como grande demais para o agente; o presente é o tempo da metamorfose no qual o herói se torna capaz de agir, de realizar a ação formidável; o terceiro tempo, que descobre o futuro, revela que a ação, o acontecimento têm uma coerência secreta que destrói o eu do agente. Assim, ao fazer confluir a terceira síntese do tempo com a potência da repetição no eterno retorno, Deleuze pode dizer que "a roda do eterno 
retorno é, ao mesmo tempo, produção da repetição a partir da diferença e seleção da diferença a partir da repetição" (DELEUZE, 1968, p.61).

A teoria diferencial das faculdades dá uma importância especial ao terceiro momento dessa ontologia do tempo, à repetição que afirma o tempo como futuro: "é um $E u$ rachado por esta forma do tempo que se encontra, enfim, coagido a pensar aquilo que só pode ser pensado, não o Mesmo, mas este 'ponto aleatório' transcendente, sempre Outro por natureza, em que todas as essências estão envolvidas como diferenciais de pensamento e que só significa a mais alta potência de pensar à força de também designar o impensável ou a impotência de pensar no uso empírico" (DELEUZE, 1988, p.188). Finalmente, em ambos os casos, o que está em questão é a afirmação da diferença e do ser do devir e tudo se conquista por afirmação, seleção e subtração: subtrair o eixo do tempo e as transcendências ao pensamento e afirmar o futuro como dimensão na qual a repetição se diz da diferença e o pensamento se diz do devir. Deleuze enfatiza o mais importante:

da sensibilidade à imaginação, da imaginação à memória, da memória ao pensamento - quando cada faculdade disjunta comunica à outra a violência que a leva ao seu limite próprio -, é a cada vez uma figura da diferença que desperta a faculdade, e a desperta como o diferente desta diferença. Tem-se, assim, a diferença na intensidade, a disparidade no fantasma, a dessemelhança na forma do tempo, o diferencial no pensamento. A oposição, a semelhança, a identidade e mesmo a analogia são apenas efeitos produzidos por estas apresentações da diferença, em vez de serem as condições que subordinam a diferença e fazem dela alguma coisa de representado (DELEUZE, 1968, p.189).

Desse modo, se o tempo é o que fissura o $E u$ e compromete a unidade do senso comum, é com a afirmação de um acordo-discordante entre as faculdades que Deleuze garante a necessidade e a permanência dos efeitos da introdução, no pensamento puro, da forma pura e vazia do tempo - o Eu rachado, o Deus morto. As subtrações, ao pensamento, do ideal do senso comum e do modelo da doxa são as operações da teoria diferencial da experiência.Vejamos:

O princípio de uma comunicação, mesmo violenta, parece manter a forma de um senso comum. Entretanto não se trata disto. Existe um 
encadeamento das faculdades e uma ordem neste encadeamento. Mas nem a ordem nem o encadeamento implicam uma colaboração sob a forma de um objeto supostamente o mesmo ou uma unidade subjetiva na natureza do Eu penso. É uma cadeia forçada e quebrada que percorre tanto os pedaços de um eu dissolvido quanto as bordas de um Eu rachado. O uso transcendente das faculdades é, propriamente falando, um uso paradoxal, que se opõe a que o exercício das faculdades se dê sob a regra de um senso comum. Além disso, o acordo das faculdades só pode ser produzido como um acordo-discordante, pois cada uma só comunica à outra a violência que a coloca em presença de sua diferença e de sua divergência com todas (DELEUZE, 1968, p.189-90).

Todo cuidado parece ser pouco quando se trata de evitar o retorno, em um outro ponto e sob uma outra roupagem, à forma do senso comum. Neste sentido, Deleuze se indaga com mais vagar: o que é que se comunica de uma faculdade a outra sem conformar um senso comum? Segundo ele, são ideias enquanto problemas que percorrem todas as faculdades (da sensibilidade ao pensamento e do pensamento à sensibilidade), proporcionando as condições para que cada faculdade encontre seu objeto próprio e conquiste seu exercício superior. Toda uma nova concepção da ideia surge em decorrência das subtrações analisadas, e esse novo conceito de ideia, isolado dos pressupostos da imagem dogmática do pensamento, exigirá, por sua vez, outras afirmações e novas subtrações.

Cumpre, agora, retomar a questão do que se torna o pensamento quando abandona os postulados de sua imagem dogmática. Ao comentar a troca de cartas entre Jaques Rivière e Antonin Artaud, Deleuze objeta que Rivière fica prisioneiro da imagem dogmática do pensamento. As dificuldades de pensar, aquelas que ele percebe e valoriza, são dificuldades empíricas - falta de método, de técnica, de aplicação ou mesmo de saúde - e são, segundo Deleuze, necessidades felizes:

não só porque impedem que a natureza de nosso pensamento devore nossa própria natureza, não só porque colocam o pensamento em relação com obstáculos que são 'fatos', sem os quais ele não chegaria a orientar-se, mas também porque nossos esforços para ultrapassá-los permitem-nos manter um ideal do eu no pensamento puro, como um 
'grau superior de identidade conosco mesmo', através de todas as variações, diferenças e desigualdades que não param de nos afetar de fato (DELEUZE, 1968, p.191).

Emerge assim a questão: se o pensamento, liberto de sua imagem dogmática (quando não possui nem uma unidade natural, nem uma unidade contratual, conquistada num senso comum), ao contrário do que supõe o postulado da Cogitatio natura universalis, torna-se uma atividade cuja natureza é devorar a nossa própria natureza, como é que sua atividade criativa, que é engendrar o pensar no pensamento, poderia preservar-se a não ser intensificando e incorporando, como elemento de sua natureza desnaturalizante, o processo de seleção criadora. Não será esta uma maneira de compreender o grito de Antonin Artaud - "Sou um genital inato!" -, que Deleuze retoma como princípio de um empirismo transcendental?

Sou um genital inato! Este é um princípio que se opõe ao inatismo, à reminiscência, mas também ao transcendental kantiano. Não decalcar o transcendental de estruturas empíricas, comprometer o conceito de transcendental não com a determinação das condições da experiência possível, mas com a gênese da experiência real, com a gênese do novo - estas são conquistas da teoria diferencial do pensamento. Fazer o pensamento depender do acaso de um encontro cujo efeito é promover o exercício transcendente das faculdades que alimenta uma discórdia — uma relação entre diferenças que não se anulam, mas que, ao contrário, se afirmam em uma síntese disjuntiva, em um acordo-discordante - é determinar as condições de uma heterogênese. $O$ pensamento como heterogênese do pensar é uma determinação do empirismo transcendental que, segundo Deleuze, dá um novo sentido ao conceito de transcendental. É preciso enfatizar: o pensamento como heterogênese é uma ideia, conquistada pela teoria diferencial da experiência que impulsiona a crítica deleuziana na direção de uma outra concepção do transcendental, na qual o pensamento se compromete com seu eterno retorno. O pensamento, ao afirmar seu eterno retorno, deixa de pretender um saber e torna-se um aprender. Aprender sem mais submeter-se ao ideal do conhecimento. Apreender como ética da imanência para o pensamento e para a vida, cujo lema é criar e não mais julgar. 


\section{4}

${ }^{1}$ Esse tema complexo, que conjuga crítica e criação como componentes do pensamento, atravessa, como uma diagonal, toda a obra de Deleuze. Contudo, ele se explicita e se repete, sobretudo, em Nietzsche e a filosofia, em Proust e os signos e em Diferença e repetição, sob um mesmo título: "A imagem do pensamento". A rigor, cada uma dessas obras submete esse tema - o que é pensar? - às questões que lhes são próprias, articulando-o a outros problemas que, contudo, comunicam-se na questão ontológica, desenvolvida especialmente em Diferença e repetição e em Lógica do sentido.

${ }^{2}$ A ideia de um outro mundo, de um mundo suprassensível com todas as suas formas (Deus, a essência, o bem, o verdadeiro), a ideia de valores superiores à vida não é um exemplo entre outros, mas o elemento constitutivo de qualquer ficção. Os valores superiores à vida não se separam de seu efeito: a depreciação da vida, a negação deste mundo. E se não se separam desse efeito é porque têm por princípio uma vontade de negar, de depreciar." (DELEUZE, 1962, p.169).

\section{Referências bibliográficas}

DELEUZE, Gilles. Nietzsche et la philosophie. Paris: PUF, 1962 [Nietzsche e a filosofia. Trad. bras. Edmundo Fernandes Dias e Ruth Joffily Dias. Rio de Janeiro: Editora RIO, 1976].

Nietzsche. Paris: PUF, 1965. (Nietzsche. Tradução

portuguesa Alberto Campos. Lisboa; Edições 70, 2009)

Le bergsonisme. Paris: PUF, 1966. [Bergsonismo. Trad. Bras.

Luiz B. L. Orlandi. São Paulo: editora 34].

Différence et Répétition. Paris: PUF, 1968. [Diferença e repetição. Trad. Bras. Luiz B. L. Orlandi e Roberto Machado. Rio de Janeiro: Graal, 1988\}.

Logique du sens. Paris: Éditions de Minuit, 1969. [Lógica do sentido. Trad. Bras. Luiz Roberto Salinas Fortes. São Paulo: Editora Perspectiva, 1974].

Superposititions. Paris: Minuit, 1979.

Francis Bacon: logique de la sensation. Paris: Éditions

Flammarion, 1981.

Foucault. Paris: Minuit, 1986. [Foucault. Trad. Bras. Claudia

Sant'Anna Martins. São Paulo: Brasiliense, 1991]. 
A dobra: Leibniz e o barroco. São Paulo: Papirus, 1991.

\& GUATTARI, F. Qu'est-ce que la philosophie? Paris:

Éditions de Minuit, 1991. [O que é a filosofia? Trad. Bras. Bento Pradro Jr. e Alberto Alonso Muñoz. São Paulo: Editora 34].

Critique et clinique. Paris: Éditions de Minuit, 1993.[Crítica e clínica. Trad. Bras. Peter Pál Pelbart. São Paulo: Editora 34, 1997]. L' île deserte et autres textes. Paris: Les Éditions de Minuit, 2002. 